\title{
RUMAH SUSUN KOMERSIAL YANG KOMPREHENSIF DENGAN PRINSIF PENGELOLAAN YANG IDEAL YANG MEMBERIKAN PERLINDUNGAN HUKUM BAGI PEMILIK DAN PENGHUNI SATUAN RUMAH SUSUN
}

\author{
Oleh: \\ Nuraini Zachman *
}

\begin{abstract}
ABSTRAK
Pembangunan Rumah Susun merupakan salah satu alternatif pemecahan masalah kebutuhan perumahan dan pemukiman terutama di daerah perkotaan yang jumlah penduduknya terus meningkat, dan pembangunan rumah susun dapat mengurangi penggunaan tanah, membuat ruang-ruang kota yang lebih lega dan dapat digunakan sebagai suatu cara untuk peremajaan kota bagi daerah yang kumuh. Banyak rumah susun dibangun dan ribuan orang tinggal di dalamnya. Akan tetapi tidak semua orang mengetahui aspek Hukum tinggal di rumah susun. Sayangnya eskalasi pembangunan rumah susun juga diikuti dengan eskalasi konflik antara penyelenggara rumah susun dan pemilik/penghuni, khususnya yang berkaitan dengan pengelolaan rumah susun. Apakah ini berarti pengaturan perundang-undangan yang telah dibuat Pemerintah dan DPR belum mampu mengakomodir hak dan kewajiban masing-masing pihak, dikarenakan minimnya akses terhadap aturan-aturan yang diperuntukkan bagi keduabelah pihak (penyelenggara rumah susun dan pemilik/penghuni rumah susun). permasalahan yang timbul dalam Pengelolaan Rumah Susun yang penulis teliti dari rumah susun komersial, dikarenakan pembangunan rumah susun komersial yang marak berlangsung saat ini menimbulkan eskalasi konflik dibidang pengelolaan rumah susun, dan tampak jelas tidak memberikan perlindungan hukum kepada Perhimpunan Pemilik dan Penghuni Satuan Rumah Susun (PPPSRS) yang merupakan entitas yang penting dan memiliki peran yang besar dalam sebuah rumah susun.
\end{abstract}

Kata Kunci : Perlindungan Hukum, Pemilik, Penghuni, Rumah Susun

\section{A. Pendahuluan}

Rumah atau tempat tinggal merupakan pintu masuk ke dunia yang menjanjikan pemenuhan kebutuhan dasar lainnya, sebagai landasan konstitusional dibidang Perumahan yang berdasarkan Pasal $28 \mathrm{H}$ ayat (1) Undang-Undang Dasar Republik Indonesia 1945 menyebutkan bahwa setiap orang berhak hidup sejahtera lahir dan bathin, bertempat tinggal, dan mendapatkan lingkungan yang baik dan sehat yang merupakan kebutuhan dasar manusia, dan mempunyai peranan strategis dalam pembentukan watak dan kepribadian bangsa serta sebagai upaya membangun manusia Indonesia seutuhnya, berjati diri, mandiri, dan produktif. Oleh karena itu

\footnotetext{
* Pengajar Program Magister Ilmu Hukum UNBARI
} 
Nuraini Zachman, Rumah Susun Komersial yang Komprehensif dengan Prinsif Pengelolaan yang Ideal yang Memberikan Perlindungan Hukum Bagi Pemilik Dan Penghuni Satuan Rumah Susun

berdasarkan Undang-Undang Republik Indonesia Nomor 1 Tahun 2011 tentang Perumahan dan Kawasan Pemukiman, dalam pertimbangan, huruf a dan b bahwa negara bertanggung jawab untuk menjamin pemenuhan hak akan tempat tinggal dalam bentuk rumah yang layak dan terjangkau di dalam perumahan yang sehat, aman, harmonis dan berkelanjutan diseluruh wilayah Indonesia.

Pembangunan Rumah Susun merupakan salah satu alternatif pemecahan masalah kebutuhan perumahan dan pemukiman terutama di daerah perkotaan yang jumlah penduduknya terus meningkat, dan pembangunan rumah susun dapat mengurangi penggunaan tanah, membuat ruang-ruang kota yang lebih lega dan dapat digunakan sebagai suatu cara untuk peremajaan kota bagi daerah yang kumuh. Sekarang ini rumah susun telah menjadi salah satu pilihan tempat tinggal yang paling popular.

Banyak rumah susun dibangun dan ribuan orang tinggal di dalamnya. Akan tetapi tidak semua orang mengetahui aspek Hukum tinggal di rumah susun. Sayangnya eskalasi pembangunan rumah susun juga diikuti dengan eskalasi konflik antara penyelenggara rumah susun dan pemilik/penghuni, khususnya yang berkaitan dengan pengelolaan rumah susun. Apakah ini berarti pengaturan perundang-undangan yang telah dibuat Pemerintah dan DPR belum mampu mengakomodir hak dan kewajiban masing-masing pihak, dikarenakan minimnya akses terhadap aturan-aturan yang diperuntukkan bagi keduabelah pihak (penyelenggara rumah susun dan pemilik/penghuni rumah susun).

Bisa jadi hal tersebut terjadi karena selama ini hanya sikap pasif masyarakat sendiri untuk mendapatkannya, atau bisa juga kurangnya sosialisasi peraturan yang semestinya intens dilakukan pemerintah. Sulit untuk menemukan siapa yang berada dalam posisi pasif. ${ }^{3}$ Ataukah ada hal lain. Oleh karena itu penulis melakukan penelitian yang berkaitan dengan permasalahan yang timbul dalam Pengelolaan Rumah Susun yang penulis teliti dari rumah susun komersial, dikarenakan pembangunan rumah susun komersial yang marak berlangsung saat ini menimbulkan eskalasi konflik dibidang pengelolaan rumah susun, dan tampak jelas tidak memberikan perlindungan hukum kepada Perhimpunan Pemilik dan Penghuni Satuan Rumah Susun (PPPSRS) yang merupakan entitas yang penting dan memiliki peran yang besar dalam sebuah rumah susun. Landasan hukum dari pada pembangunan Rumah Susun adalah UndangUndang Nomor 20 Tahun 2011 tentang Rumah Susun yang merupakan pembaharuan Undang-

${ }^{3}$ Erwin Kallo, Panduan Hukum Untuk Pemilik/Penghuni Rumah Susun (Kondominium, Apartemen dan Rusunami) (Jakarta: Minerva Athena Pressindo, Agustus 2008), hal. 1. 
Nuraini Zachman, Rumah Susun Komersial yang Komprehensif dengan Prinsif Pengelolaan yang Ideal yang Memberikan Perlindungan Hukum Bagi Pemilik Dan Penghuni Satuan Rumah Susun

Undang Nomor 16 Tahun 1985 tentang Rumah Susun yang dianggap sudah tidak lagi sesuai dengan perkembangan hukum, kebutuhan setiap orang, partisipasi masyarakat serta tanggung jawab.

Diharapkan Undang-Undang baru ini dapat menciptakan dasar hukum yang tegas sesuai dengan tujuan penyelenggaraan rumah susun yang berdasarkan asas kesejahteraan, keadilan dan pemerataan, kenasionalan, keterjangkauan dan kemudahan, keefisienan dan kemanfaatan, kemandirian dan kebersamaan, kemitraan, keserasian dan keseimbangan, keterpaduan, kesehatan, kelestarian dan berkelanjutan, keselamatan, kenyamanan serta keamanan, ketertiban dan keteraturan dengan peraturan pelaksanaannya yang belum diganti yaitu Peraturan Pemerintah Nomor 4 Tahun 1988, tentang Rumah Susun yang telah diundangkan pada tanggal 26 April 1988 dan peraturan lainnya yang berkaitan dengan penyelenggaraan Rumah Susun.

Pembangunan rumah susun salah satu langkah revitalisasi kawasan kumuh sekaligus memberikan solusi penyediaan tanah bagi hunian vertikal. Setiap peremajaan kawasan kumuh seluas 1 hektar untuk hunian vertikal akan mampu mengatasi kawasan kumuh seluas 4 hektar. Program perumahan di perkotaan menjadi penting mengingat pada Tahun 2030 sekitar $70 \%$ penduduk Indonesia akan tinggal di perkotaan. Pembangunan hunian vertikal di kota-kota besar akan mengatasi problem transportasi perkotaan yang pelik, masyarakat berpenghasilan rendah di dekatkan kelokasi kerja sehingga tidak menghabiskan pendapatan untuk ongkos transportasi. Disisi lain perlu ada sinergi antara pemerintah pusat dan daerah untuk tata ruang yang jelas dan transparan. Pembangunan Rumah Susun dewasa ini merupakan respon terhadap kebutuhan rumah bagi masyarakat dan menjadi alternatif pilihan untuk penyediaan hunian yang ideal bagi negara-negara berkembang.Daerah yang mempunyai tingkat kepadatan penduduk yang tinggi memiliki permasalahan pada kurangnya ketersediaan hunian, ketidak layakan hunian dan keterbatasan lahan. Hal ini membutuhkan suatu konsep perencanaan pembangunan yang tepat agar permasalahan hunian dapat terselesaikan.

Pada prakteknya pembangunan Rumah Susun yang marak berkembang saat ini diselenggarakan oleh pihak Swasta, belum se ideal tujuannya, para pengembang atau developer lebih mementingkan segi keuntungannya daripada tujuan untuk memenuhi kebutuhan rakyat yang berpenghasilan menengah kebawah yang dalam Undang Undang Nomor 20 Tahun 2011 disebut MBR (Masyarakat Berpenghasilan Rendah). Artinya "target user" bagi undang-undang tersebut sebenarnya adalah masyarakat berpenghasilan rendah, maka wajar jika undang-undang 
Nuraini Zachman, Rumah Susun Komersial yang Komprehensif dengan Prinsif Pengelolaan yang Ideal yang Memberikan Perlindungan Hukum Bagi Pemilik Dan Penghuni Satuan Rumah Susun

tersebut dibuat dengan menyesuaikan kebutuhan masyarakat berpenghasilan rendah. Kenyataan yang berkembang lebih dahulu adalah pembangunan Rumah Susun untuk masyarakat berpenghasilan menengah ke atas.

Berbanding terbalik dengan Pembangunan Rumah Susun Umum, Rumah Susun Khusus, Rumah Susun Negarayang peruntukkannya sebagaimana diatur dalam Undang-Undang Republik Indonesia Nomor 20 Tahun 2011 tentang Rumah Susun, yang mana pada kenyataannya Penyelenggara Rumah Susun dan penyedia modal/perbankan lebih banyak melakukan pembangunan Rumah Susun Komersial yaitu rumah susun yang diselenggarakan untuk mendapatkan keuntungan. Dalam perkembangannya Pembangunan Rumah Susun Komersial yang dikenal dengan sebutan Apartemen di tengah kota banyak diminati oleh para pelaku pembangunan dikarenakan lebih memberikan keuntungan yang besar (Profit Oriented), oleh karena itu pembangunan Rumah Susun Komersial/Apartemen tersebut menjadi parameter untuk mengukur tujuan para pengembang sebenarnya yang tidak lagi menyediakan pembangunan Rumah Susun untuk rakyat menengah ke bawah atau MBR seperti yang diatur dalam UndangUndang, tetapi lebih banyak pembangunan dilangsungkan untuk masyarakat tingkat menengah atas, baik selaku investor ataupun pemilik/owner, sehingga tujuan untuk mengentaskan kekumuhan yang berarti kemiskinan senyatanya tidak tercapai. Pola perilaku penyelenggara dan pemilik Rumah Susun komersial/Apartemen dan perbankan membentuk budaya baru bagi masyarakat rumah susun pada umumnya yang akhirnya menimbulkan domino effek berupa permasalahan yang amat beragam, seperti Pengelolaan Rumah Susun/Apartemen yang banyak timbul kepermukaan publik antara lain berhubungan dengan pungutan biaya pengelolaan yang dinamakan service charge dan sinking fund, perubahan perilaku masyarakat terhadap lingkungan tempat tinggal baru dan budaya hukum para penyelenggara dan pemilik/penghuni rumah susun/apartemen, lokasi yang tidak sesuai dengan kelayakan untuk bertempat tinggal (misalnya dekat dengan lapangan terbang), status tanah apartemen yang tidak transparan (misalnya Apartemen di Kemayoran yang berstatus tanah HGB di atas HPL), perbedaan luas bangunan, pungutan biaya parkir yang dilakukan yang melanggar Undang-Undang Nomor 20 Tahun 2011 dan Peraturan Pemerintah Nomor 4 Tahun 1988.

Permasalahan Pengelolaan Rumah Susun sering terjadi terkait dengan Perhimpunan Pemilik dan Penghuni Satuan Rumah Susun (untuk selanjutnya disebut PPPSRS). Hal demikian sehubungan dengan ketentuan Pasal 59 Undang-Undang Nomor 20 Tahun 2011 yang 
Nuraini Zachman, Rumah Susun Komersial yang Komprehensif dengan Prinsif Pengelolaan yang Ideal yang Memberikan Perlindungan Hukum Bagi Pemilik Dan Penghuni Satuan Rumah Susun

menyatakan bahwa "Pelaku pembangunan yang membangun rumah susun milik dan rumah susun komersial dalam masa transisi sebelum terbentuknya PPPSRS wajib mengelola rumah susun".

\section{B. Perumusan Masalah}

Berdasarkan uraian yang dikemukakan diatas, maka tertarik dengan permasalahan yaitu bagaimanakan mekanisme pengelolaan rumah susun komersial yang Komprehensif dengan Prinsif Pengelolaan yang Ideal dan memberikan Perlindungan Hukum bagi Pemilik dan Penghuni Satuan Rumah Susun?

\section{Mekanisme Pengelolaan Rumah Susun Komersial yang Komprehensif dengan Prinsif Pengelolaan yang Ideal yang memberikan Perlindungan Hukum bagi Pemilik dan Penghuni Satuan Rumah Susun.}

Pengelolaan Rumah Susun telah diatur dalam Bab VII tentang Pengelolaan Pasal 56, 57, 58, 59 dan 60 Undang-Undang Nomor 20 Tahun 2011 tentang Rumah Susun, dan Pasal 62, 63, 64, 65, 66, 67, 68, dan 69 serta Peraturan Pemerintah Nomor 4 Tahun 1988 tentang Rumah Susun, yang merupakan peraturan yang digunakan sebagai landasan hukum bagi Pengelolaan rumah susun yang dilakukan oleh Badan Hukum Pengelola yaitu PPPSRS yang diberi kedudukan sebagai badan hukum berdasarkan Pasal 74 ayat (3) Undang-Undang Nomor 20 Tahun 2011 tentang Rumah Susun. Pengelolaan rumah susun meliputi kegiatan-kegiatan operasional yang berupa pemeliharaan, perbaikan, dan pembangunan prasarana lingkungan, serta fasilitas sosial, bagian bersama, benda bersama, dan tanah bersama. Badan Pengelola yang ditunjuk oleh Perhimpunan Penghuni harus mempunyai status badan hukum dan profesional. Penyelenggara pembangunan ditentukan kewajibanya untuk mengelola Rumah Susun yang dibangunnya dengan jangka waktu sekurang-kurangnya 3 (tiga) bulan dan paling lama satu tahun sejak terbentuknya PPPSRS atas biaya penyelenggara pembangunan".

Seiring perkembangan pembangunan rumah susun, banyaknya timbul permasalahan yang amat beragam, seperti permasalahan yang bukan Pengelolaan, yaitu sebagai berikut :

1. Lokasi pembangunan rumah susun yang tidak sesuai dengan kelayakan untuk bertempat tinggal (misalnya Apartemen Patria Park di Halim Perdana Kusuma yang dekat dengan lapangan terbang); 
2. Status tanah apartemen yang tidak dijelaskan terlebih dahulu kepada konsumen secara transparan (misalnya Apartemen di Kemayoran yang berstatus tanah HGB diatas HPL) ;

3. Janji-janji Developer yang berhubungan dengan cara bayar dan cara penyerahan unit sarusun (seperti di Apartemen CBD Pluit dan Royal Mediterania Garden);

4. Perbedaan luas bangunan tiap-tiap unit yang sangat signifikan yang merugikan pemilik ;

5. Pungutan biaya parkir yang dilakukan yang melanggar Undang-Undang Nomor 20 Tahun 2011 dan Peraturan Pemerintah Nomor 4 Tahun 1988. Yang menyatakan bahwa benda bersama tidak boleh dikomersialkan ;

6. Pembangunan rumah susun yang tidak tepat sasaran seperti banyaknya kepemilikkan Rumah Susun bersubsidi yang bukan dimiliki oleh orang yang seharusnya memiliki, seperti Rusunami yang diperuntukkan untuk masyarakat yang berpenghasilan rendah sekarang banyak dimiliki oleh kalangan berpunya di Jakarta, tujuannya untuk investasi, dan yang menjadi incaran adalah rusunami bersubsidi di kawasan perkantoran atau perdagangan dengan prospek bagus untuk ditinggali (disewakan atau diperjual belikan) dan berbisnis. Seperti Rusunami Gading Nias, Kebagusan City, dan Kalimalang Residences ;

7. Pembangunan rumah susun yang tidak memenuhi syarat teknis yaitu tidak memenuhi tata bangunan meliputi persyaratan peruntukan lokasi serta intensitas dan arsitektur bangunan ; dan keandalan bangunan yang meliputi persyaratan keselamatan, kesehatan, kenyamanan dan kemudahan.

Sedangkan permasalahan dibidang Pengelolaan yaitu sebagai berikut :

1. Iuran pengelolaan berupa service charge dan sinking fund yang tinggi dan tidak wajar, tidak transparan dan dipisahkan menjadi asset PPPSRS ;

2. Pengelola rumah susun adalah penyelenggara pembangunan rumah susun/Developer dengan membentuk badan pengelola sendiri, seperti PT.KAS Agung Podomoro Group, dan menempatkan karyawan-karyawan penyelenggara sendiri kedalam pembentukan PPPSRS ;

3. Pada waktu melakukan Rapat Umum Perhimpunan Pemilik dan Penghuni Satuan Rumah Susun (PPPSRS), kepemilikan Developer atas rumah susun tersebut masih melebihi 50\% (belum seluruhnya laku terjual), sehingga ketika perhitungan suara 
PPPSRS yang merupakan pemilik sebenarnya kalah suara, karena perhitungan suara berdasarkan suara terbanyak ;

4. Adanya dua interpretasi ketentuan Pasal 77ayat (1) dan ayat (2) tentang Hak Suara, yaitu disebutkan dalam ayat (1) bahwa "Dalam hal PPPSRS memutuskan sesuatu yang berkaitan dengan kepemilikan dan pengelolaan rumah susun, setiap anggota mempunyai hak yang sama dengan NPP";;dalam ayat (2) disebutkan bahwa "Dalam hal PPPSRS memutuskan sesuatu yang berkaitan dengan kepentingan penghunian rumah susun, setiap anggota berhak memberikan satu suara".

Permasalahannya : Developer memakai ayat (1) karena lebih menguntungkan Developer, sedangkan PPPSRS memakai ayat (2) karena "setiap anggota hanya berhak satu suara" one man one vote, menurut PPPSRS sangatlah tidak fair jika dihitung dari NPP, karena sudah pasti Developer selaku pemilik unit terbanyak akan selalu memenangi suara dan berhak atas Pengelolaan.

Pada prakteknya pengelolaan rumah susun dimonopoli oleh penyelenggara secara terus menerus dengan berbagai alasan dan cara-cara yang sampai memakai rekayasa untuk menjadi pengelola, padahal seharusnya pengelolaan diurus dan diserahkan kepada PPPRS (Persatuan Perhimpunan Penghuni Rumah Susun) sebagaimana yang telah diatur dalam Pasal 75 UndangUndang Nomor 20 Tahun 2011 ini. Dan sampai dengan saat ini tidak ada satupun tuntutan dari para PPPSRS sampai ke Pengadilan, dikarenakan Penegak hukumpun ragu untuk mengidentifikasikan pelanggaran dan penyimpangan yang dilakukan Developer tersebut sebagai tindakan melawan hukum, dikarenakan tidak diaturnya sanksi-sanksi dalam pengaturan pengelolaan rumah susun, sehingga akhirnya konflik-konflik permasalahan pengelolaan hanya diselesaikan secara internal saja, keberpihakan para penegak hukum kepada developer tampak sangatlah memihak dengan tidak diprosesnya lebih lanjut konflik-konflik yang terjadi dalam pengelolaan rumah susun.

Melihat karakter sebagian besar Badan Pengelola Rumah Susun yang dimonopoli oleh developer atau oleh PPPSRS yang dibentuk oleh developer atau PPPSRS yang terdiri dari karyawan-karyawan developer, jelas terlihat adanya pelanggaran terhadap hak-hak Konsumen dalam hal ini adalah Pemilik/penghuni rumah susun, dan Penyelenggara Pembangunan Rusun sebagai Produsen.Seperti diketahui hubungan produsen dan konsumen memiliki tingkat 
Nuraini Zachman, Rumah Susun Komersial yang Komprehensif dengan Prinsif Pengelolaan yang Ideal yang Memberikan Perlindungan Hukum Bagi Pemilik Dan Penghuni Satuan Rumah Susun

ketergantungan yang cukup tinggi. ${ }^{4}$ Hubungan hukum antara produsen dan konsumen telah terjadi sejak proses produksi, distribusi, pemasaran dan penawaran. ${ }^{5}$

Di Barat, perlindungan konsumen semakin mendapat pengakuan yang kuat pascaJhon $\mathrm{F}$ Kennedy menyampaikan consumen message dihadapan Kongres Amerika Serikat pada Tahun 1962, ia mengemukakan bahwa ada 4 (empat) hak konsumen yang harus dilindungi, yaitu: ${ }^{6}$

1. Hak memperoleh keamanan (the right to safety)

Aspek ini ditujukan pada perlindungan konsumen dari pemasaran barang dan/atau jasa yang membahayakan keselamatan konsumen.Pada posisi ini, intervensi, tanggung jawab dan peranan pemerintah dalam rangka menjamin keselamatan dan keamana konsumen sangat penting. Karena itu pula, pengaturan dan regulasi perlindungan konsumen sangat dibutuhkan untuk menjaga konsumen dari perilaku produsen yang nantinya dapat merugikan dan membahayakan keselamatan konsumen.

2. Hak memilih (the right to choose)

Bagi konsumen, hak memilih merupakan hak prerogatif konsumen apakah ia akan membeli atau tidak membeli suatu barang dan/atau jasa. Oleh karena itu tanpa ditunjang oleh hak untuk mendapatkan informasi yang jujur, tingkat pendidikan yang patut, dan penghasilan yang memadai, maka hak ini tidak akan banyak artinya. Apalagi dengan meningkatnya teknik penggunaan pasar, terutama lewat iklan, maka hak untuk memilih ini lebih banyak ditentukan oleh faktor-faktor di luar diri konsumen.

3. Hak mendapat informasi (the right to be informed)

Hak ini mempunyai arti yang sangat fundamental bagi konsumen bila dilihat dari sudut kepentingan dan kehidupan ekonominya. Setiap keterangan mengenai sesuatu barang yang akan dibelinya atau akan mengikat dirinya, haruslah diberikan selengkap mungkin dan dengan penuh kejujuran. Informasi baik secara umum melalui berbagai media komunikasi seharusnya disepakati bersama agar tidak menyesatkan konsumen.

4. Hak untuk didengar (the right to be heard).

Hak ini dimaksudkan untuk menjamin konsumen bahwa kepentingannya harus diperhatikan dan tercermin dalam kebijaksanaan pemerintah, termasuk turut didengar dalam

\footnotetext{
${ }^{4}$ Sudaryatmo, Masalah Perlindungan Konsumen di Indonesia, Jakarta, 1996, hal 23.

${ }^{5}$ Basu Swastia, Manajemen Modern Yogyakarta:Liberty,1997 hal 25.

${ }^{6}$ Vernon A.Mosselman dan John H Jackson, Introduction to Modern Business, diterjemahkan Kusma Widiadisastra Jakarta: Erlangga, 1992, hal. 294-295
} 
Nuraini Zachman, Rumah Susun Komersial yang Komprehensif dengan Prinsif Pengelolaan yang Ideal yang Memberikan Perlindungan Hukum Bagi Pemilik Dan Penghuni Satuan Rumah Susun

pembentukan kebijakan tersebut. Selain itu konsumen juga harus didengar setiap keluhannya dan harapannya dalam mengkonsumsi barang dan/atau jasa yang dipasarkan produsen.

YLKI menambahkan satu hak dasar lagi sebagai pelengkap empat dasar hak dasar konsumen yang dikemukakan yang dikemukakan oleh John F.Kennedy, yaitu hak mendapatkan lingkungan hidup yang baik dan sehat.Sehingga keseluruhannya dikenal sebagai "Panca Hak Konsumen".

Sebagian besar dari Pemilik/penghuni Rumah Susun pada waktu awal membeli rumah susun hanya diberikan selembar surat pemesanan yang harus ditandatangani, dalam surat pemesanan tersebut diatur mengenai cara pembayaran dan besarnya down payment, selanjutnya setelah pembangunan rumah susun rampung $20 \%$ minilal maka antara penyelenggara dengan pembeli menandatangani Perjanjian pendahuluan yang disebut Perjanjian Pengikatan Jual Beli, dimana dalam perjanjian tersebut terdapat perikatan antara Penjual dan Pembeli dengan ketentuan-ketentuan yang pembeli tidak bisa merubahnya, karena perusahaan didalam membuat perjanjian bersandarkan pada klausula baku yang pasti menguntungkan pihak penjual.

Teori due care tentang kewajiban perusahaan terhadap konsumen didasarkan pada gagasan, bahwa pembeli dan konsumen tidak saling sejajar, dan kepentingan konsumen sangat rentan terhadap tujuan perusahaan yang memiliki pengetahuan dan keahlian yang tidak dimiliki konsumen.

Kenapa peneliti memasukan Undang-Undang Perlindungan Konsumen dalam Disertasi ini? Secara Yuridis sangat beralasan, Rumah susun komersial atau rumah susun umum adalah produk dari penyelenggara pembangunan rumah susun. Ketika produknya dijual atau dialihkan berarti seluruh hak-hak dan kewajiban-kewajiban dari Penjual telah beralih kepada Pembeli selaku konsumen. Pengelolaan yang dilakukan oleh developer selama 3 bulan atau selambatlambatnya satu tahun dengan segala pengeluaran ditanggung oleh developer. Didalam jual beli tanah dan bangunan itu dapat diartikan sebagai garansi atas pembangunan yang diselenggarakan developer. Konsumen mempunyai hak untuk mengekpresikan apa yang menjadi pendapat dan keluhannya terhadap barang yang dijual termasuk menuntut hak-haknya konsumen atas pengelolaan rumah susun sebagaimana telah diatur dalam Undang-Undang Rumah Susun Nomor 20 Tahun 2011 dalam pasal-pasal tersebut diatas. Penulis mencoba untuk melakukan pengintegrasian Undang-Undang Perlindungan Konsumen kedalam UURS Nomor 20 Tahun 2011. Agar perlindungan terhadap hak-hak konsumen tidak lagi dilaksanakan secara parsial, 
namun dilaksanakan dengan pendekatan terpadu, utuh, dan universal dengan peraturan perundang-undangan lainnya sesuai dengan ketentuan Undang-Undang Perlindungan Konsumen yang bertujuan untuk:

1. Meningkatkan kesadaran, kemampuan, dan kemandirian konsumen untuk melindungi diri.

2. Mengangkat harkat dan martabat konsumen dengan cara menghindarkan konsumen dari ekses negatif pemakaian barang dan/atau jasa.

3. Meningkatkan pemberdayaan konsumen dalam memilih, menentuukan, dan menuntut hak-haknya sebagai konsumen

4. Menciptakan sistem perlindungan konsumen yang mengandung unsure kepastian hukum dan keterbukaan informasi serta akses untuk mendapatkan informasi.

5. Menumbuhkan kesadaran pelaku usaha mengenai pentingnya perlindungan konsumen sehingga tumbuh sikap yang jujur dan bertanggung jawab dalam berusaha.

6. Meningkatkan kualitas barang dan/atau jasa yang menjamin kelangsungan usaha produksi barang dan/atau jasa, kesehatan, kenyamanan, keamanan dan keselamatan konsumen.

Ketentuan tersebut diselenggarakan sebagai usaha bersama berdasarkan 5 asas yang relevan dalam pembangunan nasional, yaitu:

1. Asas manfaat, dimaksudkan untuk mengamanatkan bahwa segala upaya dalam penyelenggaraan perlindungan konsumen harus memberikan manfaat sebesar-besarnya bagi kepentingan konsumen dan pelaku usaha secara keseluruhan.

2. Asas Keadilan dimaksudkan agar partisipasi seluruh rakyat dapat diwujudkan secara maksimal damn memberikan kesempatan kepada konsumen dan pelaku usaha untuk memperoleh haknya dan melaksanakan kewajibannya secara adil.

3. Asas Keseimbangan dimaksudkan untuk memberikan keseimbangan antara kepentingan konsumen, pelaku usaha, dan pemerintah dalam arti materiel ataupun spiritual.

4. Asas Keamanan dan keselamatan konsumen dimaksudkan untuk memberikan jaminan atas keamanan dan keselamatan kepada konsumen dalam penggunaaan, pemakaian dan pemanfaatan barang dan/atau jasa yang dikonsumsi atau digunakan. 
5. Asas Kepastian Hukum dimaksudkan agar baik pelaku usaha maupun konsumen mentaati hukum dan memperoleh keadilan dalam penyelenggaraan perlindungan konsumen, serta Negara menjamin kepastian hukum.

Setelah penulis meninjau permasalahan pengelolaan dari konsep Undang-Undang Perlindungan konsumen yang tepat digunakan sebagai landasan bagi perlindungan hukum terhadap konsumen dalam hal ini pemilik satuan rumah susun, penulis juga menelaah beberapa permasalahan yang timbul dari ketidak tegasan peraturan perundang-undangan yaitu pengaturan pengelolaan pada Undang-Undang Nomor 20 Tahun 2011 dan Peraturan Pemerintah Nomor 4 Tahun 1988 tentang Rumah Susun, yang mana ketidak tegasan peraturan menyebabkan peraturan tidak efektif.

Di Indonesia, untuk melindungi kepentingan konsumen dalam mengkonsumsi barang dan/atau jasa, maka Pemerintah mengeluarkan kebijakan pengaturan hak-hak konsumen melalui Undang-Undang Nomor 8 Tahun 1999 tentang Perlindungan Konsumen. Pembentukan UndangUndang tersebut merupakan bagian dari implementasi sebagai negara kesejahteraan, karena Undang-Undang Dasar 1945 disamping sebagai konstitusi politik juga dapat disebut sebagai konstitusi ekonomi yang mengadung ide negara kesejahteraan.

Beberapa argumentasi penting tentang pentingnya intervensi pemerintah terkait dengan perlindungan konsumen, yakni : Pertama, dalam masyarakat modern, produsen menawarkan berbagai jenis produk yang diproduksi secara massal (mass production and consumption), Kedua, hasil produksi dengan cara massal dan teknologi canggih, potensial bagi munculnya resiko produk cacat, tidak memenuhi standar (substandard), dan bahkan berbahaya (hazardous product) yang merugikan konsumen. Ketiga, hubungan antara konsumen dan produsen berada pada posisi yang tidak seimbang, Keempat, persaingan yang sempurna perfect competition) sebagai pendukung consumer sovereignti theory dalam praktiknya jarang terjadi.

Sesungguhnya setiap perusahaan harus memiliki tanggung jawab sosial (corporate social responsibility).

Intervensi pemerintah sangat dibutuhkan dalam pembangunan ekonomi, ${ }^{7}$ Untuk menetapkan dan menegakkan peraturan perundang-undangan dalam bidang ekonomi, termasuk pengaturan konsumen. Namun jika tidak ada intervensi Pemerintah dalam bidang ekonomi, maka

\footnotetext{
${ }^{7}$ Bismar Nasution, Mengkaji Ulang Hukum sebagi landasan Pembangunan Ekonomi, Medan: Universitas Sumatera Utara,2004, hal 4
} 
hal ini dapat menimbulkan distorsi ekomoni. ${ }^{8}$ Pandangan ini berpendapat bahwa ekonomi hanya berfungsi bila ada kerangka hukum yang melandasinya. Melalui Undang-Undang Nomor 8 Tahun 1999 tentang Perlindungan Konsumen, Pemerintah mengatur hak-hak konsumen yang harus dilindungi. Undang-Undang Perlindungan Konsumen bukanlah anti terhadap produsen, namun sebaliknya malah merupakan apresiasi terhadap hak-hak konsumen secara universal. Produsen dalam Islam berkaitan erat dengan pekerjaan, yaitu suatu aktivitas yang dilakukan seseorang dengan mengeluarkan seluruh potensinya untuk mencapai tujuan tertentu. Karena produksi terkait dengan proses memberi nilai tambah bagi manusia, maka produksi yang dilakukan harus berdasarkan amal kebaikan. Oleh karena itu, produksi dalam ekonomi Islam tidak sekedar untuk meningkatkan material saja dengan tujuan duniawi, tetapi juga untuk meningkatkan moral sebagi sarana untuk mencapai tujuan ukhawi. Islam tidak mengatur hak-hak konsumen berurutan seperti dalam Undang-Undang Perlindungan Konsumen. Namun Islam melindungi hak-hak konsumen dari perbuatan curang dan informasi yang menyesatkan, serta memberikan hak atas keselamatan dan kesehatan, hak untuk memilih, hak untuk mendapatkan lingkungan yang sehat, hak untuk mendapatkan advokasi dan penyelesaian sengketa, dan hak untuk mendapatkan ganti rugi.

Pada hakikatnya, tanggung jawab sosial Perusahaan terhadap konsumen merupakan kepentingan perusahaan itu sendiri guna merebut kepercayaan publik yang kemudian bergerak kearah pemetikan hasil dari kepercayaan publik tersebut. Pengaturan perlindungan konsumen tidak dimaksudkan untuk mematikan atau melemahkan usaha dan aktivitas pelaku usaha, tetapi justru sebaliknya, sebab, perlindungan konsumen diharapkan mampu mendorong iklim dan persaingan usaha yang sehat. Dengan demikian, diharapkan dapat melahirkan perusahaan yang tangguh dalam menghadapi persaingan sehat melalui penyediaan barang dan/atau jasa yang berkualitas. Hubungan Hukum antara Produsen dan Konsumen telah mengalami perubahan konstruksi hukum, yakni hubungan yang semula dibangun atas prinsip"caveat emptor" berubah menjadi"capeat venditor"

Undang-Undang Konsumen dengan Pengelolaan rumah susun sangat tepat untuk diintegrasikan dalam setiap permasalahannya. Pelaku pembangunan bertanggung jawab atas apa yang diproduksinya dalam hal ini rumah susun, yang telah dialihkannya haknya kepada Pemilik

\footnotetext{
${ }^{8}$ Didik J.Rachbini, Ekonomi Politik, Paradigma, Teori Pilihan Publik, Jakarta: Ghalia Indonesia,2002, hal
} 106 
dan penghuni Satuan rumah susun, sehingga ketika terjadi penyimpangan dan pelanggaran terhadap hak-hak yang dimiliki oleh Pemilik dan Penghuni rumah susun atas Pengelolaan yang seharusnya menjadi kewenangan PPPSRS, maka Pelaku Pembangunan dapat dikenakan PasalPasal yang diatur dalam Undang-Undang Perlindungan Konsumen, dimana dalam UndaangUndang tersebut norma-norma yang dilanggar semuanya berdampak pidana.

Agar norma-norma yang ada dalam Undang-Undang Nomor 20 Tahun 2011 menjadi efektif, maka harus dilakukan perubahan dengan memasukan sanksi-sanksi dan mengintegrasikan Undang-Undang Perlindungan Konsumen di dalam implementasinya menghadapi permasalahan yang terjadi dalam rumah susun termasuk masalah pengelolaan. Dan didalam membuat perubahan hendaknya memakai pandangan tentang efektivitas hukum yang dikemukakan oleh Clearence J. Dias, Howard dan Mummers. Clearence J. Dians yaitu lima syarat bagi efektif tidaknya suatu sistem hukum. Kelima syarat itu, meliputi:

1) Mudah tidaknya makna atau isi aturan-aturan hukum itu ditanggapi;

2) Luas tidaknya kalangan di dalam masyarakat yang mengetahui isi aturan-aturan yang bersangkutan;

3) Efisien dan efektif tidaknya mobilisasi aturan-aturan hukum yang dicapai dengan bantuan:

a) Aparat administrasi yang menyadari kewajibannya untuk melibatkan dirinya ke dalam usaha mobilisasi yang demikian;

b) Para warga masyarakat yang merasa terlibat dan merasa harus berpartisipasi di dalam proses mobilisasi hukum;

4) Adanya mekanisme penyelesaian sengketa yang tidak hanya harus mudah dihubungi dan dimasuki oleh setiap warga masyarakat, akan tetapi juga harus cukup efektif menyelesaikan sengketa; dan

5) Adanya anggapan dan pengakuan yang merata di kalangan warga masyarakat, bahwa aturan-aturan dan pranata-pranata hukum itu memang sesungguhnya berbeda mampu efektif. ${ }^{9}$

\footnotetext{
${ }^{9}$ Marcus Priyo Gunarto, Kriminalisasi dan Penalisasi Dalam Rangka Fungsionalisasi Perda Pajak dan Retribusi, Semarang : Program Dokter Ilmu Hukum Universitas Diponogoro, 2008, hal. 71-72.
} 
Pendapat yang lain tentang efektivitas hukum dikemukakan oleh Howard dan Mummers. Kedua ahli itu mengemukakan delapan syarat agar hukum dapat berlaku secara efektif.Kedelapan syarat itu, disajikan berikut ini.

(1) Undang-Undang harus dirancang dengan baik, kaidah-kaidah yang mematoki harus dirumuskan dengan jelas dan dapat dipahami dengan, penuh kepastian. Tanpa patokanpatokan yang jelas seperti itu, orang sulit untuk mengetahui apa yang seseungguhnya diharuskan, sehingga undang-undang tidak akan efektif.

(2) Undang-Undang itu, seyogyanya bersifat melarang, dan bukannya bersifat mengharuskan. Dapat dikatakan bahwa hukum prohibitur itu pada umumnya lebih mudah dilaksanakan ketimbang hukum mandatur.

(3) Sanksi yang diancamkan dalam undang-undang itu harus ada korelasinya dengan sifat undang-undang yang dilanggar. Suatu sanksi yang mungkin tepat untuk suatu tujuan tertentu, mungkin saja akan dianggap tidak tepat untuk tujuan lain.

(4) Berat sanksi yang diancamkan pada si pelanggar tidaklah terlalu berat. Sanksi yang terlalu berat dan tak seimbang dengan macam pelanggarannya akan menimbulkan keengganan dalam hati para penegak hukum (khususnya para juri) untuk menerapkan sanksi itu secara konsekuensi terhadap orang-orang golongan tertentu.

(5) Kemungkinan untuk mengamati dan menyidik perbuatan-perbuatan yang dikaidahi dalam undang-undanag harus ada. Hukum yang dibuat untuk melarang perbuatanperbuatan yang sulit dideteksi, tentulah tidak mungkin efektif. Itulah sebabnya hukum berkehendak mengontrol kepercayaan-kepercayaan atau keyakinan-keyakinan orang tidak mungkin akan efektif.

(6) Hukum yang mengandung larangan-larangan moral akan jauh efektif ketimbang hukum yang tak selaras dengan kaidah-kaidah moral, atau yang netral. Seringkali kita menjumpai hukum yang demikian efektifnya, sehingga seolah-olah kehadirannya tak diperlukan lagi, karena perbuatan-perbuatan yang tak dikehendaki itu juga sudah dicegah oleh daya kekuatan moral dan norma sosial. Akan tetapi, ada juga hukum yang mencoba melarang perbuatan-perbuatan tertentu sekalipun kaidah-kaidah moral tak berbicara apa-apa tentang perbuatan itu, misalnya larangan menunggak pajak. Hukum seperti itu jelas kalah efektif jika dibandingkan dengan hukum yang mengandung paham dan pandangan moral di dalamnya. 
(7) Agar hukum itu bisa berlaku secara efektif, mereka yang bekerja sebagai pelaksanapelaksana hukum harus memenuhui tugas dengan baik. Mereka harus mengumumkan undang-undang secara luas.Meraka harus menafsirkannya secara seragam dan konsisten, serta sedapat mungkin senapas atau senada dengan bunyi penafsiran yang mungkin juga dicoba dilakukan oleh warga masyarakat yang terkena. Aparat-aparat penegak hukum harus juga bekerja keras tanpa mengenal jemu untuk menyidik dan menuntut pelanggar-pelanggar.

(8) Akhirnya agar suatu undang-undang dapat efektif, suatu standar hidup sosio-ekonomi yang minimal harus ada di dalam masyarakat. Pula, di dalam masyarakat ini, ketertiban umum sedikit atau banyak harus mudah terjaga. ${ }^{10}$

Dari delapan syarat itu, maka dapat dipilih menjadi tiga syarat supaya aturan hukum dikatakan efektif. Ketiga syarat itu, meliputi:

(a) Undang-Undangnya;

(b) Adanya pelaksana hukum; dan

(c) Kondisi sosio-ekonomi masyarakat.

Undang-Undang yang dibuat dan ditetapkan harus:

I Dirancang dengan baik;

II Substansinya, meliputi:

A. Bersifat melarang;

B. Mengandung sanksinya. Sanksinya tidak terlalu berat;

C. Mengandung moralitas.

Pelaksana hukum adalah aparat yang melaksanakan hukum itu sendiri, seperti kepolisian, kejaksaan, KPK, dan pengadilan. Pelaksana hukum ini harus melaksanakan tugasnya dengan baik. Efektivitas hukum harus dilihat pada kondisi sosio-ekonomi masyarakat. Semakin baik ekonomi masyarakat, maka semakin efektif undang-undang tersebut, hal ini disebabkan masyarakat yang bersangkutan tidak ada yang akan melakukan pelanggaran hukum. Semakin rendah ekonomi masyarakat, maka semakin banyak terjadi pelanggaran hukum. Hal ini dapat dilihat dalam masyarakat, yang ekonominya rendah, maka tingkat pencurian menjadi meningkat jumlahnya.

\footnotetext{
${ }^{10}$ Ibid, hal. 69-90.
} 
Nuraini Zachman, Rumah Susun Komersial yang Komprehensif dengan Prinsif Pengelolaan yang Ideal yang Memberikan Perlindungan Hukum Bagi Pemilik Dan Penghuni Satuan Rumah Susun

Berpedoman pada teori ini diharapkan aktor-aktor yang terlibat dalam penelitian ini seperti Badan Hukum Pengelolaan bentukan Pengembang/Developer, PPPSRS, masyarakat pemerhati Rumah Susun, para penegak hukum dan para ahli semakin memahami permasalahan yang terjadi dalam bidang Pengelolaan Rumah Susun, sehingga didapatkan solusi yang berkeadilan bagi semua stakeholder, dengan tetap memberikan perlindungan hukum kepada para pemilik/penghuni Rumah Susun yang sangat berperan di dalam pembangunan Rumah Susun dan menjadi landasan serta motivasi bagi para penegak hukum untuk melaksanakan sanksi yang tegas atas subjek hukum yang melakukan pelanggaran, sehingga terwujudnya:

1. Peranan Hukum dalam Penyelesaian Sengketa Pengelolaan Rumah Susun;

2. Perlindungan Hukum bagi para pelaku pengelolaan dan penghuni Satuan Rumah Susun.

Dari hasil penelitian empiris penulis ke lokasi rumah susun yang ada konflik pengelolaan, dan dari teori-teori mengenai Budaya Hukum dari Lawrence M.Friedman dan efektivitas hukum sebagaimana yang telah diuraikan, sangat jelas bahwa pengaturan rumah susun yang dilakukan oleh penyelenggara rumah susun tidak efektif sebagaimana disebutkan dalam Pasal 59 ayat (1) Undang-Undang Nomor 20 Tahun 2011 tentang Rumah Susun, disebutkan bahwa "Pelaku Pembangunan yang membangun rumah susun milik dan rumah susun komersial dalam masa transisi sebelum terbentuknya PPPSRS (Persatuan Perhimpunan Penghuni Satuan Rumah Susun) wajib mengelola rumah susun".

Kegagalan pelaksanaan pengaturan pengelolaan tersebut dikarenakan pasal tersebut mempunyai peluang bagi penyelenggara untuk melanggengkan kepentingannya terhadap rumah susun yang dibangunnya, pengertian masa transisi tersebut berpijak pada penyerahan rumah susun pertama kali yang menurut Pasal 60 Undang-Undang Nomor 20 tahun 2011 ini diatur dengan Peraturan Pemerintah sampai dengan saat ini belum ada Peraturan Pemerintah yang relevan dengan ketentuan Pasal 60 ini, dan harusnya Developer telah memperhitungkan waktu penyerahan unit tersebut secara tegas pada saat unit di pesan oleh pembeli, janji pengembang untuk menyerahkan itu harus dituangkan kedalam Perjanjian awal antara Developer dan pembeli, sehingga langkah selanjutnya seperti pengertian MASA TRANSISI yang diatur dalam ayat (2) dapat diketahui waktunya kapan terjadi pengelolaan yang dibentuk PPPSRS terlaksana sebagaimana pengertian dalam Pasal 59 ayat (2), masa transisi sebagaimana dimaksud pada ayat (1) ditetapkan paling lama 1 (satu) tahun sejak penyerahan pertama kali sarusun kepada pemilik. 
Menetapkan dan menerapkan sanksi terhadap pelanggaran yang telah ditetapkan dalam Anggaran Dasar dan Anggaran Rumah Tangga.Pengelolaan rumah susun (rusun) dan apartemen bukanlah suatu hal yang mudah.Oleh karena itu, penyelesaian 'konflik' pengelolaan rusun lewat aturan main yang jelas, sudah menjadi kebutuhan yang tak bisa ditunda-tunda lagi.

Pemerintah harusnya melakukan pengawasan yang intensif kepada penyelenggara rumah susun, sehingga pembangunan yang dilakukannya juga memenuhi asas keadilan guna mensejahterakan rakyat, para pengembang tidak hanya mencari keuntungan tetapi juga harus memperhatikan kemanfaatannya. Sekarang ini penyelenggara rumah susun hanya melihat dari segi bisnis saja yaitu mencari keuntungan yang sebesar-besarnya, jika bisa keuntungan selamalamanya, pengusaha mau mendapatkan untung yang besar dari penjualan unit-unit rumah susun dan akhirnya melebar mencari keuntungan dari peluang pelaksanaan pengelolaan rumah susun. Kolaburasi antara penyelenggara dan pemberi izin lahan dan tata ruangpun marak terjadi, terjadi simbiosis mutualistis antara mereka, dan para penegak hukum tidak berbuat apa-apa atas penyimpangan-penyimpangan tersebut. Sebaiknya pengaturan pengelolaan rumah susun dalam Undang-Undang Nomor 20 Tahun 2011 tentang Rumah Susun ditambahkan dengan sanksisanksi atas pelanggaran/penyimpangan yang dilakukan penyelenggara pembangunan ataupun PPPSRS. Agar adil keduanya harus duduk bersama untuk mencari solusi yang memungkinkan win-win solution.

Atas pengaturan pengelolaan yang telah ada, hendaknya PPPSRS diberi kemudahan untuk membentuk badan hukum Pengelolaan rumah susun asalkan profesional, tranparan, dan bertanggung jawab.Terhadap hambatan yang sering terjadi mengenai masalah dokumentasi yang tidak dilengkapi oleh Penyelenggara Pembangunan untuk menghambat pembentukan badan hukum oleh PPPSRS, perlunya pemerintah mengeluarkan aturan yang tegas kepada Penyelenggara Pembangunan untuk menyerahkan dokumentasi legalitas dan perizinan kepada PPPSRS dengan memberikan batas jangka waktu jangka waktu penyerahan, jika lewat jangka waktu tersebut maka Penyelenggara Pembangunan dikenakan denda atas setiap hari keterlambatan penyerahannya. Dengan demikian pengaturan pengelolaan akan efektif berjalan sesuai dengan ketentuan dalam Undang-Undang yang ada dengan penambahan pada Peraturan Pemerintah atau Peraturan Menteri yang didasarkan hal-hal tersebut.

Bagaimanapun rumitnya konflik di bidang pengelolaan rumah susun, tetap bahwa pembangunan adalah penting dan wajib berkesinambungan, tidak ada satu negarapun yang tidak 
menyelenggarakan pembangunan, termasuk pembangunan perumahan bagi rakyat. Menyadari kondisi ini hendaknya pemerintah berusaha mencari formulasi kebijakan yang tepat di bidang Pengelolaan rumah susun, sehingga dalam penyelenggaraan perumahan dapat memenuhi keadilan, memberi manfaat yang optimal, serta memberikan jaminan kesejahteraan dan kepatian hukum sesuai dengan tujuannya ${ }^{11}$ yaitu untuk mengendalikan lajunya pembangunan rumahrumah biasa yang banyak memakan lahan. Penulis mengingatkan akan adanya dua perspektif yang dapat dilihat dalam merespon realitas atau fenomena tersebut, pertama perspektif internal (internal perspective) dan kedua perspektif eksternal (external perspective). Dilihat dari perspektif internal, memang tidak tampak adanya hal-hal yang penting untuk dipermasalahkan atas realitas empiris dimana para penegak hukum tidak menerapkan ketentuan yang menempatkan Badan Hukum Pengelola rusun yang tidak transparan dalam penggunaan dana pengelolaan yang dipungut dari sinking fund dan service charge sebagai subjek hukum tindak pidana penggelapan. Artinya sah-sah saja dan tidak ada larangan bagi para penegak hukum tidak menerapkan ketentuan tersebut meskipun fakta-fakta merujuk kearah itu.Hal ini merupakan ranah kewenangan dan kebebasan para penegak hukum dalam menempatkan subjek hukum tindak pidana penggelapan apakah perorangan ataukah korporasi.dan penegak hukum tidak keliru dalam batas-batas koridor hukum yang benar.

Sementara itu, perspektif ekternal hukum melihat bahwa bekerjanya hukum tidak hanya terbatas pada hanya dipenuhinya prosedur formal semata. Bekerjanya hukum, pertama-tama memang ditentukan dan dibatasi oleh patokan-patokan formal yang dapat diketahui dari perumusan-perumusan dalam berbagai peraturan hukum. Dalam konteks tersebut Lawrence M. Friedman menyatakan bahwa berhasil atau tidaknya penegakan hukum bergantung pada: "substansi hukum, struktur hukum/pranata hukum dan budaya hukum". Substansi Hukum adalah bagian substansial yang menentukan bisa atau tidaknya hukum itu dilaksanakan.Substansi juga berarti produk yang dihasilkan oleh orang yang berada dalam sistem hukum yang mencakup keputusan yang mereka keluarkan, atau aturan baru yang mereka susun.Substansi juga mencakup hukum yang hidup (living law), bukan hanya aturan yang ada dalam kitab undang-undang.

Untuk mewujudkan mekanisme Pengelolaan Rumah Susun Komersial yang ideal dan komprehensif serta memberikan perlindungan hukum bagi Pemilik dan Penghuni Satuan Rumah

\footnotetext{
${ }^{11}$ Fungsi sosial Hak Atas Tanah Dalam Pengadaan Tanah untuk kepentingan umum (DR. Lieke Lianadevi Tukgali, SH, MH, Mkn, hal. 4
} 
Susun Komersial berkaitan dengan Pengelolaan sebagaimana termuat dalamBAB VII UndangUndang Nomor 20 Tahun 2011 tentang Rumah Susun dan ketentuan Pengelolaan dalam Peraturan Pemerintah Nomor 4 Tahun 1988 tentang Pengelolaan Rumah Susun, maka diperlukannya pengaturan sebagai berikut :

1. Sebaiknya untuk pengelolaan rumah susun komersial di Indonesia khususnya di kotakota besar seperti Jakarta, menunjuk Badan Hukum dibidang Pengelolaan Rumah Susun yang Independen seperti di negara Singapore lepas dari pengaruh Penyelenggara Pembangunan dan lepas dari pengaruh PPPSRS, Badan Pengelola tersebut haru bertanggung jawab kepada Badan Pengawas (Surveyor) yang bertanggung jawab langsung kepada Kementerian di Bidang Pembangunan, dengan mana antara Penyelenggara Pembangunan, PPPSRS dan Badan Pengelola membuat suatu Perjanjian/Kontrak Pengelolaan dengan klausula yang jelas yang menerapkan Hak dan Kewajiban Para Pihak serta sanksi-sanksi atas pelanggarannya. Sanksi harus berupa pidana dan perdata, sebagai alat pemaksa untuk tertib hukum. Dan sanksi tersebut wajib dilaksanakan oleh Para Penegak Hukum tanpa celah negosiasi, sehingga memberikan Perlindungan bagi PPPSRS.

2. Jika tetap ingin mempertahankan Pengelolaan sesuai dengan ketentuan dalam Bab VII Undang-Undang Nomor 20 Tahun 2011 tentang Rumah Susun, maka sebaiknya aturan tersebut di evaluasi kembali dan dituangkan khusus dalam Peraturan Pemerintah tentang Pengelolaan Rumah Susun secara komprehensif dan antisipatif terhadap aturan dan ketentuan serta sanksi-sanksi bagi setiap pelanggaran yang terjadi di bidang Pengelolaan Rumah Susun yang dilakukan oleh badan pengelola.

3. Dalam Pengelolaan sebaiknya Pelaku Pembangunan dan PPPSRS duduk bersama untuk menyumbangkan pikiran, pendapat dan langkah-langkah pembentukan penyelenggaraan pengelolaan rumah susun yang ideal dan menguntungkan keduabelah pihak, yaitu menguntungkan pihak penyelenggara pembangunan yang behubungan dengan image dan trust/kepercayaan daripada konsumen dan calon konsumen untuk produk seller selanjutnya guna kesinambungan pembangunan. Disamping itu memberikan kedaulatan yang bertanggung jawab dan tranparan kepada PPPSRS untuk melaksanakan kegiatan pengelolaan dengan membentuk badan pengelola yang terdiri dari PPPSRS atau Badan Pengelola yang independen yang berkompeten dan bertanggung jawab. 


\section{Kesimpulan}

Mekanisme pengaturan rumah susun di Indonesia telah memiliki perundang-undangan yang berlaku diartikan bahwa Rumah Susun adalah bangunan gedung bertingkat yang dibangun dalam suatu lingkungan yang terbagi dalam bagian-bagian yang distrukturkan secara fungsional, baik dalam arah horizontal maupun vertikal dan merupakan satuan-satuan yang masing-masing dapat dimiliki dan digunakan secara terpisah, terutama untuk tempat hunian yang dilengkapi dengan bagian bersama, benda bersama, dan tanah bersama. Satuan rumah susun merupakan milik perseorangan yang dikelola sendiri oleh pemiliknya, sedangkan bagian bersama, benda bersama dan tanah bersama merupakan milik bersama yang dikelola bersama oleh pemilik dan penghuni rumah susun yang dinamakan PPPSRS (Perhimpunan Pemilik dan Penghuni Rumah Susun), yang berdasarkan Pasal 74 ayat (3) Undang-Undang Nomor 20 tahun 2011 tentang Rumah Susun, diberi kedudukan sebagai Badan Hukum, yang berkewajiban mengurus kepentingan para pemilik dan penghuni yang berkaitan dengan pengelolaan kepemilikan benada bersama, bagian bersama, tanah bersama dan penghunian.

\section{E. Daftar Pustaka}

Erwin Kallo, Panduan Hukum Untuk Pemilik/Penghuni Rumah Susun (Kondominium, Apartemen dan Rusunami, Jakarta: Minerva Athena Pressindo, 2008

Sudaryatmo, Masalah Perlindungan Konsumen di Indonesia, Jakarta, 1996

Basu Swastia, Manajemen Modern, Yogyakarta:Liberty, 1997

Vernon A.Mosselman dan John H Jackson, Introduction to Modern Business, penerjemah Kusma Widiadisastra, Jakarta: Erlangga, 1992

Inosentisu Samsul Perlindungan Konsumen Kemungkinan Penerapan Tanggung Jawab Mutlak, Jakarta : Universitas Indonesia, 2004

Bismar Nasution, Keterbukaan dalam Pasar Modal, Jakarta: Program Pasca Sarjana Universitas Indonesia, 2001

Mariam Darus Badrul Zaman, Pembentukan Hukum Nasional dan Permasalahannya, Bandung: 1981

Arif Budiman, Corporate Social Responsibility, Jawaban bagi Model Pembangunan Indonesia Masa Kini, Jakarta : ICSD, 2002.

Bismar Nasution, Mengkaji Ulang Hukum sebagi landasan Pembangunan Ekonomi Medan: Universitas Sumatera Utara, 2004.

Didik J.Rachbini, Ekonomi Politik, Paradigma, Teori Pilihan Publik, Jakarta: Ghalia Indonesia, 2002

A.Sony Keraf, Pasar Bebas, Keadilan dan Peranan Pemerintah, Jakarta, 1996

Yusuf Sofie, Perlindungan Konsumen dan Instrumen-instrumen Hukumnya, Bandung, Citra 
Nuraini Zachman, Rumah Susun Komersial yang Komprehensif dengan Prinsif Pengelolaan yang Ideal yang Memberikan Perlindungan Hukum Bagi Pemilik Dan Penghuni Satuan Rumah Susun

Monzer Kahf, Ekonomi Islam, Yogyakarta: Pustaka Pelajar, 1995.

Marcus Priyo Gunarto, Kriminalisasi dan Penalisasi Dalam Rangka Fungsionalisasi Perda Pajak dan Retribusi, Semarang : Program Dokter Ilmu Hukum Universitas Diponogoro, 2008.

Esmi Warassih, Pranata Hukum (Sebuah Telaah Sosiologis), Semarang: PT. Suryandaru Utama, 2005. 